\title{
Congenital myotonic dystrophy-an RNA-mediated disease across a developmental continuum
}

\author{
Sujatha Jagannathan ${ }^{1,2,3}$ and Robert K. Bradley ${ }^{1,2}$ \\ ${ }^{1}$ Computational Biology Program, Public Health Sciences Division, Fred Hutchinson Cancer Research Center, Seattle, Washington \\ 98109, USA; ${ }^{2}$ Basic Sciences Division, Fred Hutchinson Cancer Research Center, Seattle, Washington 98109, USA; ${ }^{3}$ Human \\ Biology Division, Fred Hutchinson Cancer Research Center, Seattle, Washington 98109, USA
}

Thomas and colleagues (pp. 1122-1133) demonstrate severe dysregulation of developmentally regulated alternative splicing and polyadenylation in congenital myotonic dystrophy (CDM). In doing so, they also highlight the importance of these post-transcriptional processes during normal fetal muscle development. Finally, they generate and characterize a mouse model of CDM that lacks all three Muscleblind-like proteins.

Regulated RNA processing enables the synthesis of a diverse proteome from a compact set of coding genes during development, differentiation, and other cellular processes. Dysregulated RNA processing plays correspondingly critical roles in both inherited human diseases and cancer (Dvinge et al. 2016; Scotti and Swanson 2016).

Myotonic dystrophy type I (DM1), an archetype of RNA-mediated disease, is caused by the presence of an expanded CTG trinucleotide repeat within the DMPK gene. The corresponding CUG repeats within the $3^{\prime}$ untranslated region of DMPK mRNA fold into a stem-loop structure that binds and sequesters Muscleblind-like (MBNL) proteins, preventing them from carrying out their normal roles in RNA processing (Miller et al. 2000). Functional inactivation of MBNL proteins causes defects in RNA splicing and localization that drive DM1 (Kanadia et al. 2003; Wang et al. 2012).

Inheritance of very long CTG repeat structures causes a severe form of DM1 called congenital myotonic dystrophy (CDM). Unlike individuals affected by adult-onset DM1, who do not have symptoms at birth, CDM-affected neonates exhibit hypotonia (low muscle tone) and respiratory problems. The differing clinical presentations of CDM and adult-onset DM1 presumably arise from the inheritance of a long repeat array in CDM versus postnatal somatic expansion of the repeat in adult-onset disease

[Keywords: congenital myotonic dystrophy; MBNL; microsatellite; myoblast; myogenesis; RNA processing] Corresponding author: rbradley@fredhutch.org Article is online at http://www.genesdev.org/cgi/doi/10.1101/gad.302893. 117.
(Wong et al. 1995). However, the precise molecular mechanisms underlying the severity and early onset of CDM are unknown.

MBNL1 sequestration results in fetal isoform expression in adult muscle, a reversion to developmentally inappropriate splicing that cannot support adult muscle function (Lin et al. 2006). This pathomechanism accounts for most splicing changes observed in models of adult-onset DM1 (Du et al. 2010). However, it is unknown whether similar mechanisms occur in CDM. Thomas et al. (2017) addressed this question by showing that disrupted RNA processing also underlies CDM pathology, with key differences from adult-onset DM1 that may explain the severity and the early onset of CDM.

Thomas et al. (2017) first quantified splicing dysregulation in CDM by comparing the skeletal muscle transcriptomes of CDM-affected infants with disease control (spinal muscular atrophy type I) and healthy control transcriptomes. They identified hundreds of potentially disease-relevant isoforms that were differentially spliced in CDM muscle relative to controls as well as dysregulated alternative polyadenylation. CDM muscle transcriptomes recapitulated missplicing patterns that were identified recently as biomarkers in a large cohort of adult-onset DM1 (Wagner et al. 2016). Notably, CDM was associated with more extreme missplicing of these shared biomarkers. For example, quantitative comparison of the inferred MBNL concentration with missplicing of $M E F 2 D$, encoding a transcriptional activator that is important for muscle development, showed that the inferred functional MBNL concentration inversely correlated with MEF2D missplicing across control, adult-onset DM1, and CDM muscle samples. CDM tissue had the lowest inferred functional MBNL concentration and more extreme differential splicing relative to adult-onset DM1 samples. These results indicate that CDM is a spliceopathy like adult-onset DM1,

(C) 2017 Jagannathan and Bradley This article is distributed exclusively by Cold Spring Harbor Laboratory Press for the first six months after the fullissue publication date (see http://genesdev.cshlp.org/site/misc/terms. xhtml). After six months, it is available under a Creative Commons License (Attribution-NonCommercial 4.0 International), as described at http://creativecommons.org/licenses/by-nc/4.0/. 
albeit with more severe splicing dysregulation that is presumably due to the presence of long CTG repeats in the prenatal genome.

Having established the severity of RNA misprocessing in postnatal CDM muscle, Thomas et al. (2017) next tackled the timing of misregulation. In adult-onset DM1, pathogenic RNA misprocessing occurs postnatally. In contrast, CDM exhibits early, with in utero onset of disease. Thomas et al. (2017) therefore tested whether RNA misprocessing similarly occurred in utero in CDM-affected individuals. The investigators first assessed whether splicing transitions are widespread during skeletal muscle development in utero. They combined RNA sequencing data sets from in vitro muscle differentiation and fetal muscle tissues to identify splicing events that exhibited monotonic changes in exon inclusion during myogenesis. Many of these events exhibited developmental reversion in CDM. For example, CDM muscle exhibited preferential exclusion of BIN1 exon 11, resembling immature myoblasts. BIN1 is a critical regulator of membrane tubulation during muscle differentiation, and reducing BIN1 exon 11 inclusion is sufficient to cause myopathy in vivo (Fugier et al. 2011). The investigators' transcriptome analyses also revealed that DMPK mRNA was expressed more highly in muscle precursor cells and fetal muscle than in mature muscle, which could cause increased expression of toxic CUG ${ }^{\text {exp }}$ RNA in utero in CDM-affected individuals. These analyses suggested that CDM is characterized by dysregulated prenatal splicing and reversion of developmental splicing transitions that are important for muscle development.

Thomas et al. (2017) next sought to establish murine models of CDM. First, they showed that conditional knockout of Mbnl1 and Mbnl2 recapitulated much of the spliceopathy and several phenotypes of CDM but resulted in more modest differential gene expression than they observed in CDM. The investigators then hypothesized that loss of all three $\mathrm{Mbnl}$ genes might model CDM more accurately and so generated a conditional triple knockout. Double-knockout and triple-knockout animals exhibited relatively similar spliceopathy. However, triple-knockout animals also exhibited modest missplicing of hundreds of additional events as well as dramatic increases in differential gene expression relevant to the clinical presentation of CDM, including impaired muscle development, respiratory distress, and perinatal lethality. Therefore, the new triple-knockout model is a valuable tool for further study of CDM pathogenesis.

The impact of this study extends beyond providing new data sets and animal models for studying CDM. It offers insight into the role of RNA processing during fetal development and highlights the importance of the relative levels of RNA molecules and their cognate RNA-binding proteins (RBPs) during critical developmental time points. For example, Thomas et al. (2017) showed that MBNL3 frequently acts antagonistically to MBNL1 and MBNL2 to promote adult pattern isoforms. How does the loss of all three factors, which act both antagonistically and concordantly, give rise to the quantitative splicing changes observed in this study's mouse models? More generally, how does functional inactivation of specific factors by toxic RNA species result in broad disruption of RNA processing homeostasis and genome-wide spliceopathy? Thomas et al. (2017) demonstrated that answering this question requires a quantitative understanding of RNARBP interactions during the development of both healthy and diseased tissues.

\section{Acknowledgments}

We acknowledge the support of Ellison Medical Foundation AGNS-1030-13 (R.K.B.), National Institutes of Health/National Institute of Neurological Disorders and Stroke P01 NS069539 (R. K.B.), and Facioscapulohumeral Muscular Dystrophy Society FSHS-22014-01 (S.J.).

\section{References}

Du H, Cline MS, Osborne RJ, Tuttle DL, Clark TA, Donohue JP, Hall MP, Shiue L, Swanson MS, Thornton CA, et al. 2010. Aberrant alternative splicing and extracellular matrix gene expression in mouse models of myotonic dystrophy. Nat Struct Mol Biol 17: 187-193.

Dvinge H, Kim E, Abdel-Wahab O, Bradley RK. 2016. RNA splicing factors as oncoproteins and tumour suppressors. Nat ReV Cancer 16: 413-430.

Fugier C, Klein AF, Hammer C, Vassilopoulos S, Ivarsson Y, Toussaint A, Tosch V, Vignaud A, Ferry A, Messaddeq N, et al. 2011. Misregulated alternative splicing of BIN1 is associated with $\mathrm{T}$ tubule alterations and muscle weakness in myotonic dystrophy. Nat Med 17: 720-725.

Kanadia RN, Johnstone KA, Mankodi A, Lungu C, Thornton CA, Esson D, Timmers AM, Hauswirth WW, Swanson MS. 2003. A muscleblind knockout model for myotonic dystrophy. Science 302: 1978-1980.

Lin X, Miller JW, Mankodi A, Kanadia RN, Yuan Y, Moxley RT, Swanson MS, Thornton CA. 2006. Failure of MBNL1-dependent post-natal splicing transitions in myotonic dystrophy. Hum Mol Genet 15: 2087-2097.

Miller JW, Urbinati CR, Teng-Umnuay P, Stenberg MG, Byrne BJ, Thornton CA, Swanson MS. 2000. Recruitment of human muscleblind proteins to (CUG)(n) expansions associated with myotonic dystrophy. EMBO I 19: 4439-4448.

Scotti MM, Swanson MS. 2016. RNA mis-splicing in disease. Nat Rev Genet 17: 19-32.

Thomas JD, Sznajder ŁJ, Bardhi O, Aslam FN, Anastasiadis ZP, Scotti MM, Nishino I, Nakamori M, Wang ET, Swanson MS. 2017. Disrupted prenatal RNA processing and myogenesis in congenital myotonic dystrophy. Genes Dev (this issue). doi: 10.1101/gad.300590.117.

Wagner SD, Struck AJ, Gupta R, Farnsworth DR, Mahady AE, Eichinger K, Thornton CA, Wang ET, Berglund JA. 2016. Dose-dependent regulation of alternative splicing by MBNL proteins reveals biomarkers for myotonic dystrophy. PLoS Genet 12: e1006316.

Wang ET, Cody NAL, Jog S, Biancolella M, Wang TT, Treacy DJ, Luo S, Schroth GP, Housman DE, Reddy S, et al. 2012. Transcriptome-wide regulation of pre-mRNA splicing and mRNA localization by muscleblind proteins. Cell 150: 710-724.

Wong LJ, Ashizawa T, Monckton DG, Caskey CT, Richards CS. 1995. Somatic heterogeneity of the CTG repeat in myotonic dystrophy is age and size dependent. Am J Hum Genet 56: 114-122. 


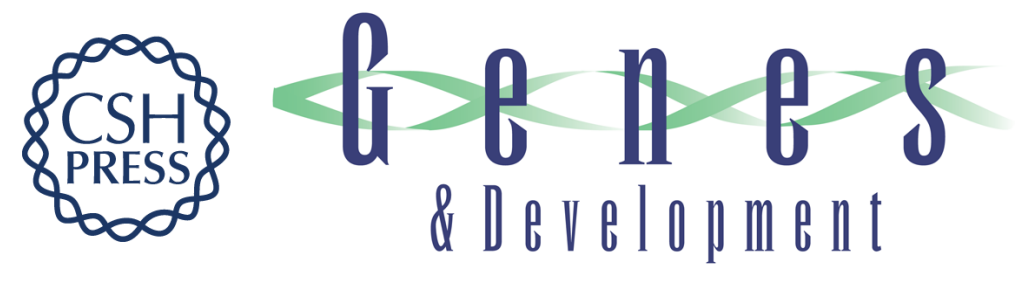

\section{Congenital myotonic dystrophy--an RNA-mediated disease across a developmental continuum}

Sujatha Jagannathan and Robert K. Bradley

Genes Dev. 2017, 31:

Access the most recent version at doi:10.1101/gad.302893.117

\section{Related Content Disrupted prenatal RNA processing and myogenesis in congenital myotonic dystrophy \\ James D. Thomas, Lukasz J. Sznajder, Olgert Bardhi, et al. Genes Dev. June, 2017 31: 1122-1133 \\ References This article cites 11 articles, 3 of which can be accessed free at: http://genesdev.cshlp.org/content/31/11/1067.full.html\#ref-list-1 \\ Articles cited in: \\ http://genesdev.cshlp.org/content/31/11/1067.full.html\#related-urls \\ Creative This article is distributed exclusively by Cold Spring Harbor Laboratory Press for the first Commons License six months after the full-issue publication date (see http://genesdev.cshlp.org/site/misc/terms.xhtml). After six months, it is available under a Creative Commons License (Attribution-NonCommercial 4.0 International), as described at http://creativecommons.org/licenses/by-nc/4.0/. \\ Email Alerting Receive free email alerts when new articles cite this article - sign up in the box at the top Service right corner of the article or click here.}

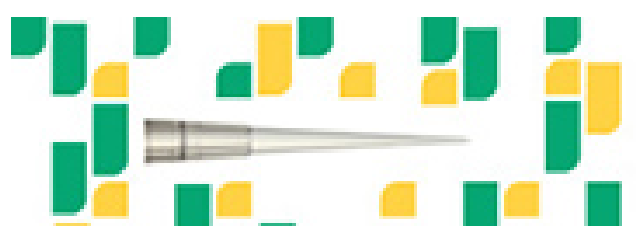

Focused on your science. 